\title{
PARLIAMENTARY SCRUTINY OF LEGISLATION UNDER THE HUMAN RIGHTS ACT 1998
}

\author{
Anthony Lester QC
}

The enactment of the Human Rights Act 1998 in the United Kingdom has widely affected many aspects of the operation of Government, including the traditional separation of judiciary, legislature, and executive. This paper examines the scope and process adopted for the scrutiny of legislation within the framework of the Human Rights Act 1998. The particular focus canvasses the first year's operation of the Joint Committee on Human Rights and its role as watchdog.

\section{INTRODUCTION}

Our system of democratic government, like yours, is based upon the constitutional theory of parliamentary rather than executive government. In theory, Parliament is the supreme legislative authority and controls the executive. In practice, of course, the executive proposes legislation and is usually able to get its way in making legislation, with the loyal support of its built-in parliamentary majority. The parliamentary scrutiny of legislation is an often hurried and cursory procedure, subject to the timetable imposed by government business managers and the disciplinary powers of their agents, the Whips.

As for the parliamentary scrutiny of treaties, and compliance with treaty obligations, that is even weaker than is the scrutiny of legislative proposals. The ratification even of treaties with major constitutional implications, such as the International Covenant on Civil and Political Rights ("the Covenant") or the European Convention on Human Rights ("the Convention") is done under prerogative powers, with no requirement for Parliamentary approval. The reports by the government to international human rights bodies - such as the United Nations Human Rights Committee, the Committee Against Torture, the Committee for the Elimination of Racial Discrimination, the Committee for the Elimination of Discrimination Against Women and the Committee on the Rights of the Child - are not

* Practising member of Blackstone Chambers, Temple, London EC4Y 9BW, and Liberal Democrat Peer. The author is grateful to Jane Gordon and Angela Patrick, Parliamentary Legal Officers of the Odysseus Trust, for their assistance in preparing this paper. 
systematically scrutinised or debated by Parliament, nor are the recommendations made by them for changes in United Kingdom legislation or practice.

We do have powerful scrutiny committees of both Houses of Parliament to examine proposed European Union legislation, ${ }^{1}$ but the making of treaties and compliance with the international obligations they impose remains largely the province of the executive branch.

Some years ago, I introduced a Private Member's Bill to enhance parliamentary scrutiny. It led to the introduction of explanatory memoranda laid before Parliament before important treaties are ratified, ${ }^{2}$ but, so far, successive governments have opposed the creation of a dedicated treaty scrutiny committee in either House. ${ }^{3}$

However, one notable way in which parliamentary accountability is being enhanced comes in the wake of the Human Rights Act 1998 ("the HRA"). The creation of a Joint Committee on Human Rights ("the Joint Committee") establishes a new parliamentary watchdog and bloodhound. The Joint Committee has already strengthened the role of Parliament in scrutinising legislative proposals and administrative practices against the standards set by the European Convention on Human Rights and the other international human rights codes by which the United Kingdom is bound.

\section{SCRUTINY UNDER THE HUMAN RIGHTS ACT 1998}

These developments promoting good governance and democracy under the rule of law in the United Kingdom spring from seeds sown in Wellington. As you will recall, the final report of the Justice and Law Reform Committee on the proposals in Sir Geoffrey Palmer's radical 1985 White Paper, A Bill of Rights for New Zealand?, was opposed to an entrenched Bill of Rights limiting the legislative powers of Parliament. ${ }^{4}$ The Justice and Law Reform Committee recommended that the Bill of Rights should not be able to override inconsistent legislation, but should be merely declaratory, affirming New Zealand's commitment to the

1 House of Commons European Scrutiny Committee and the House of Lords Select Committee on the European Union. Details of both Committees can be found at <http:/ /www.parliament.uk> (last accessed 20 June 2002).

2 Treaties (Parliamentary Approval) Bill 1996, Second Reading Debate: (28 February 1996) 569 GBPD cols 1530-64 (HL).

3 The Royal Commission on the Reform of the House of Lords (the Wakeham Commission) recommended that the Liaison Committee should consider the establishment of a Treaty Scrutiny Committee. The Commission notes in its Report, A House for the Future, that "[t]he proposed Committee would provide exactly the mechanism we believe is required to carry out the technical scrutiny of such treaties" (at 91). The government responded to a parliamentary question on the point, confirming that it would be for the Liaison Committee to consider the issue: Hansard (HL) Vol 616, Official report, cols 1127-1131 (2 October 2001).

4 Justice and Law Reform Committee final report, 1988. 
International Covenant on Civil and Political Rights. However, the Justice and Law Reform Committee proposed that parliamentary scrutiny of legislative proposals for consistency with such a Bill of Rights should be enhanced. It recommended the inclusion of a provision requiring the Attorney General to report to Parliament if a Bill derogated from the Bill of Rights. That recommendation was later enacted as section 7 of the New Zealand Bill of Rights Act 1990 (the "BORA"). ${ }^{5}$

The Human Rights Act 1998 has a New Zealand pedigree, based as it is upon the interpretative model found in the BORA. But section 19 of the HRA goes much further than section 7 of the BORA. ${ }^{6}$ It requires a Minister in charge of a Bill before Second Reading, to make one of two statements. This will be either a statement that in her view the provisions of the Bill are compatible with Convention rights or in the event that she cannot make a statement of compatibility in relation to the particular Bill, a statement that the Government wishes to proceed with the Bill in any event.

Section 19 requires Ministers and their respective departments specifically to consider the impact on Convention rights of each new Bill they seek to introduce. In this way, the Minister responsible for the Bill assumes individual responsibility for Convention

5 Formal legal advice is provided to the Attorney General in relation to every Bill, regarding its consistency with the BORA. The Ministry of Justice provides formal advice on every Bill introduced to Parliament, except those Bills for which it has responsibility. The Crown Law Office provides advice in relation to Ministry of Justice Bills. (See the Attorney General's Memorandum: Monitoring Bills for Compliance with the New Zealand Bill of Rights Act 1990). On the basis of this advice, the Attorney General decides whether to advise Parliament that the legislative proposals are incompatible with the rights protected by the BORA. The Attorney-General, if the AttorneyGeneral intends to report on a government Bill, must do so on the introduction of that Bill to Parliament. Where any other Bill, such as a private member's Bill, is concerned he must report as soon as practicable after its introduction. Clause 3 of my second Private Member's Bill took a leaf out of the BORA by providing that, where a Bill introduced into either House of Parliament by a Minister of the Crown contains any provision which is or appears to be inconsistent with the Convention rights, notification shall be sent by the Minister to the Lord Chancellor and to the Speaker of the House of Commons drawing attention to the inconsistency or apparent inconsistency and explaining the reasons for the inconsistency or apparent inconsistency.

6 Section 19 provides that:

"(1) A Minister of the Crown in charge of a Bill in either House of Parliament must, before Second Reading of the Bill -

(a) make a statement to the effect that in his view the provisions of the Bill are compatible with the Convention rights ("a statement of compatibility"); or

(b) make a statement to the effect that although he is unable to make a statement of compatibility the government nevertheless wishes the House to proceed with the Bill.

(2) The statement must be in writing and be published in such manner as the Minister making it considers appropriate". 
compliance. ${ }^{7}$ Before the passing of the HRA, few, if anyone, in Whitehall or Westminster appreciated just how significant the practical impact of section 19 procedure would be upon the preparation and interpretation of proposed legislation.

The New Zealand Cabinet Manual requires Ministers to draw attention to any aspects of Bills that have implications for, or may be affected by, the rights and freedoms contained in the BORA or the Human Rights Act 1993. ${ }^{8}$ The British Cabinet Office Guidance to Departments (the "CO Guidance") is more detailed. It requires a two-stage advice process as to the compatibility of Bills. ${ }^{9}$ At the policy approval stage, a general assessment is made, not necessarily as a free-standing document, to alert Ministers to substantive Convention issues. Once the Bill is drafted, a more formal compatibility document is prepared by departmental lawyers in consultation with Law Officers and the Foreign and Commonwealth Office. This document is then passed to the Cabinet Legislation Joint Committee and ultimately forms the basis of the section 19 statement in each House.

The CO Guidance sets out the criteria for making a section 19 statement of compatibility; ${ }^{10}$ "a Minister must be clear that, at a minimum, the balance of argument supports the views that the provisions are compatible", and that "the provisions of the Bill will stand up to challenge on Convention grounds before the domestic courts and the Strasbourg Court". ${ }^{11}$ It also addresses the question of disclosure to Parliament of the thinking behind section 19 statements, stating: "The Minister should be ready to give a general outline of the arguments which led him or her to the conclusion reflected in the statement. Although it would not normally be appropriate to disclose to Parliament the legal advice to Ministers (or to involve Counsel in Committee proceedings if it is a draft Bill), officials should ensure that the Minister is briefed in such a way as to enable him or her at least to identify the Convention points considered and the broad lines of the argument". ${ }^{12}$

7 Under section 7 of the BORA, the Attorney General and the Ministry of Justice may approach the government department involved in the preparation of a Bill prior to its introduction to Parliament in order to resolve any difficulties with initial drafts. This additional pre-legislative stage has frequently solved many inconsistencies in legislative proposals.

8 Cabinet Office Cabinet Manual (2001) (Cabinet Office, Wellington, 2001). See the section on Compliance with Legal Principles and Obligations, at paragraphs 5.35-5.39.

9 Cabinet Office "The Human Rights Act 1998 Guidance for Departments" (February 2000) para 34.

10 Cabinet Office, above, para 36.

11 Cabinet Office, above.

12 Cabinet Office, above, para 39. 
Section 19 does not apply to delegated legislation. However, the CO Guidance explains that "as a matter of good practice" Ministers should "volunteer a view" on compatibility in respect of affirmative instruments and secondary legislation which amends primary legislation. ${ }^{13}$ Section 19 does not extend to Private Members' Bills, so there is no duty for the Member introducing such a Bill to make a statement regarding its compatibility with Convention rights. Nor does section 19 apply to compatibility with other international human rights treaties by which the United Kingdom is bound, such as the International Covenant on Civil and Political Rights. But, as I shall explain, the Joint Committee has regard to these other human rights instruments in the course of its scrutiny work.

One of the potential limitations to the scrutiny systems, under both the BORA and section 19 of the HRA, is the absence of provision to cater for amendments to Bills as they proceed through Parliament. ${ }^{14}$ The Attorney General is required by section 7 of the BORA to comment on Bills only as and when they are introduced. She cannot report upon any amendments introduced during their passage. Similarly, under the HRA, the Minister responsible for a Bill is not required to reconsider his section 19 statement as the Bill passes through each of its stages. ${ }^{15}$ Professor Anthony Bradley has stated that "such lapses are more likely in the unicameral Parliament at Wellington than at Westminster". ${ }^{16}$ It would be presumptuous for me to comment on this suggestion that New Zealand needs to restore a second legislative chamber.

The Joint Committee, on which I am privileged to serve, has remedied this potential gap in our new scrutiny system. Should any amendment come before either House which engages significant human rights issues, it is within the Joint Committee's remit to examine the issue and to bring it to the attention of both Houses of Parliament. ${ }^{17}$

13 This follows an undertaking given by Lord Williams of Mostyn during the passage of the Immigration and Asylum Bill 1999, in response to a report by the Lords delegated Powers and Deregulation Committee, 22nd Report 1998-1999; (2 November 1999) GBPD col 737 (HL).

14 Highlighted by the controversy over section 80 of the New Zealand Criminal Justice Act 1985, as considered by the New Zealand Court of Appeal in $R v$ Pora [2001] 2 NZLR 37, and in $R v$ Poumako [2000] 2 NZLR 695.

15 The Government has confirmed that the Explanatory Notes relating to a Bill will be updated when a Bill is transferred from the House of Commons to the House of Lords and again on completion of the Bill's passage in order to take account of any amendments to the Bill or any significant human rights issues raised in debate: (19 March 2002) 632, GBPD, WA 127 (HL).

16 Professor Anthony Bradley "Conflicting Statutory Provisions - the impact of fundamental human rights" [2001] NLJ 312.

17 The Committee accepted this as an issue to be resolved in its First Report, Session 2000-01, para 1. Scrutinising its first Bill, the Criminal Justice and Police Bill 2001, the Committee noted that "the Bill seemed to provide a good vehicle for exploring ways of approaching amendments introduced 


\section{THE PARLIAMENTARY JOINT COMMITTEE ON HUMAN RIGHTS}

It is the work of the Joint Committee that has given section 19 its potency. ${ }^{18}$ I note that the New Zealand Justice and Law Reform Committee's Report proposed a similar scrutiny committee for New Zealand, ${ }^{19}$ but the proposal was not subsequently adopted. ${ }^{20}$

The Joint Committee, armed with its expert legal adviser, Professor David Feldman, ${ }^{21}$ and two parliamentary Clerks, is able to monitor the operation of section 19 of the HRA

to Bills during their passage through either House, which would not be covered by the statement made under section 19(1)a".

18 The establishment of the Committee was first envisaged in the Government's White Paper, Rights Brought Home (CM 3782, 1997) paragraphs 3.7-3.8. However, the Government delayed the creation of such a committee until 14 December 1998, when the Leader of the House of Commons, the Rt. Hon. Margaret Beckett MP made the statement: "I am pleased to announce today that both houses will be asked to appoint a Joint Committee on Human Rights. It is intended to set up that Committee before the Human Rights Act 1998 comes fully into force so that it will have time to prepare its work". (14 December 1998) 332 GBPD col 604 (HL). See further, Robert Blackburn, A Human Rights Committee for the United Kingdom Parliament - The Options [1998] EHRLR 534-555. In fact, the Joint Committee on Human Rights was not established for another three years. The first meeting of the Committee was not held until 31 January 2001. Its origin lay in a proposal made in 1994 by Lords Simon of Glaisdale. Alexander of Weedon, Irvine of Lairg and myself suggested that the House of Lords should set up systems to check Bills against the European Convention on Human Rights and other human rights treaties: see Second Reading debate on Human Rights Bill, (16 February 1998) 306 GBPD col 855 (HL), Mike O'Brien MP, Minister of State. I had canvassed this idea in my maiden speech shortly after being appointed to the House of Lords: Hansard HL Vol. 550, Official report, col 170 (23rd November 1993).

19 The Committee suggested (Final Report, 11) that Standing Orders could be amended to establish a Parliamentary Joint Committee to examine Bill of Rights matters. In particular, all Bills and Regulations could stand referred to the Committee which would be empowered to examine them and report to the House on any inconsistency with any of the rights in the Bill. The Committee could also be empowered to examine any enactments and report to the House on such enactments either on its own initiative or on receipt of a written complaint from a member of the public.

20 See also Standing Order 24 of the Senate of the Australian Commonwealth Parliament which requires the Senate, at the commencement of every Parliament, to appoint a Standing Committee -" to report in respect of clauses of bills introduced into the Senate, and in respect of Acts of the Parliament, whether such bills or Acts, by express words or otherwise:

(i) trespass unduly on personal rights or liberties;

(ii) make rights, liberties or obligations unduly dependent upon insufficiently defined administrative powers;

(iii) make right, liberties or obligations unduly dependent upon non-reviewable decisions;

(iv) inappropriately delegate legislative powers; or

(v) insufficiently subject the exercise of legislative powers to parliamentary scrutiny"

21 See David Feldman Parliamentary Scrutiny of Legislation and Human Rights [2002] PL 323. 
speedily and effectively, and reports to each House of Parliament its views as to the compatibility or lack of compatibility of legislative proposals. We meet at least once a week during the parliamentary session and have recently been authorised by each House to take evidence not only within the United Kingdom but also overseas. Indeed, we hope to be able to come to New Zealand to inform our inquiry into whether a Human Rights Commission is needed in the United Kingdom ${ }^{22}$.

Within the first year of its existence, between February 2001 and March 2002, the Joint Committee completed 18 reports, ${ }^{23}$ took evidence from Ministers, legal experts and NGOs, and established itself as a key component of the legislative process. The Joint Committee's terms of reference are wide and general. We are empowered to consider matters relating to human rights in the United Kingdom (but excluding consideration of individual cases). Special mention is made to remedial orders, of which I shall speak later.

The Joint Committee is not restricted to questioning Ministers only on Convention issues and section 19 statements. We are at liberty to question Ministers on compatibility questions arising from the United Kingdom's other international human rights obligations, including the Covenant and the specialist UN Conventions. In this way, we have been able to consider the impact of the UN Convention on the Rights of the Child on proposed child curfew orders, and the impact of the Covenant on proposed travel restriction orders, in the context of our review of the Criminal Justice and Police Bill. Similarly, we noted in relation to the Anti-Terrorism, Crime and Security Bill that the Government's intention to derogate from the Convention would have an impact upon the United Kingdom's obligations under the Covenant, from which it might have to derogate.

The Joint Committee regards the scrutiny of legislation for compatibility with human rights as a central part of its work. At our second meeting, we interpreted our terms of

22 In April 2001, the Committee decided that one if its early activities should be to consider whether it would be desirable for a Human Rights Commission to be established to exercise functions in connection with the protection and promotion of human rights in the United Kingdom: see JCHR Call for Evidence, Human Rights Commission for the United Kingdom (26 April 2001).

23 For further information on the Joint Committee and for online copies of the Committee Reports, see <http:/ / www.parliament.uk/commons/selcom/hrhome.htm> (last accessed 20 June 2002). To date, the Committee has published Reports on the following Bills and Orders: the Criminal Justice and Police Bill; the Homelessness Bill; the Anti-Terrorism, Crime and Security Bill; the Proceeds of Crime Bill; the Sex Discrimination (Election Candidates) Bill; the Mental Health Act 1983 (Remedial) Order 2001; the Tobacco Advertising and Promotion Bill; the Animal Health Bill; the Employment Bill; the Police Reform Bill and various Private Members' Bills: see the Committee's Fourteenth Report, Session 2001-02, Scrutiny of Bills: Private Members' Bills (8 March 2002). There is a marked difference in the extent of scrutiny by the Attorney General and the Ministry of Justice under section 7 BORA, and the Joint Committee. Since 1990, the Attorney General has reported to Parliament on some 22 Bills. 
reference as including "a power to examine the impact of legislation and draft legislation on human rights in the United Kingdom". ${ }^{24}$ In our most recent report on Scrutiny of Bills, we emphasised that: the Joint Committee "considers itself to be responsible to Parliament for assessing whether these "section 19 statements" have been properly made, and believes this to be a key duty. Accordingly, the Joint Committee in the last Parliament announced that it would make scrutiny of primary legislation for its compatibility with Convention rights its first priority. ${ }^{25}$

The Joint Committee scrutinises legislation for compatibility in a way similar to the approach adopted by the courts in assessing claims of human rights violations. The Joint Committee considers first whether the legislation interferes potentially with any of the Convention rights. If a potential interference is apparent, the Joint Committee considers next the reasons advanced by the responsible Minister to justify the interference, applying the principles of legal certainty and proportionality. ${ }^{26}$

24 First Report, Session 2000-01, Criminal Justice and Police Bill (26 April 2001).

25 Fourteenth Report, Session 2001-02, Scrutiny of Bills: Private Members Bills \& Private Bills (8 March 2002), para 1.

26 As defined in Annex 2 of the Committee's First Report, Session 2000-01, Criminal Justice and Police Bill (26 April 2001).

The principle of legal certainty requires that if an interference with a right is to be justifiable, it must be lawful, and that (1) the law must be adequately accessible and (2) a norm cannot be regarded as law unless it is formulated with sufficient precision to enable the citizen to regulate his conduct.

The principle of proportionality requires decision-makers, contemplating an interference with a right, to balance the severity of the interference with the intensity of the social need for action. Proportionality has a number of elements. The following factors are relevant:

An interference must not take away the very essence of a right.

There must be a sufficient factual basis for believing that there was a real danger to the interest which the State claims there was a pressing social need to protect.

The State's measure or act must interfere with the right in question no more than is reasonably necessary in order to achieve the legitimate aim.

Measures are likely to be regarded as disproportionate if they impose heavy burdens on one individual or group, apparently arbitrarily, in order to achieve a social benefit, or if they impose penalties which appear to be excessive in relation to the circumstances of the offence to which they relate.

The effectiveness of any legal controls over the measures in question, and the adequacy of compensation or legal remedies for those affected by the measures, will be relevant to the proportionality of any interference. 


\section{A Examples of the Joint Committee's Approach to Scrutiny}

\section{The Criminal Justice and Police Bill}

As one of its first tasks, the Joint Committee examined the Criminal Justice and Police Bill 2001. This had to be done at breakneck speed because we were set up after the Bill had already had been debated in the Commons. We obtained oral and written evidence from the Home Office and several NGOs, and the Report drew attention to our concerns about key provisions in the Bill. We concluded that human rights issues were not engaged by many provisions and that, in light of the operation of the HRA, other provisions could be justified. We recommended amendments and additional safeguards for some provisions, such as the power for travel restriction orders to be made against drug trafficking offenders, the imposition of child curfew schemes and powers which would apparently permit speculative searches of fingerprint and DNA databases.

Several amendments were tabled on the basis of the Joint Committee's Report, and the Report was used to challenge the government's proposals. ${ }^{27}$ While the government did not make or accept many amendments to the Bill, the Minister did give an assurance that administrative guidance would be given to meet some of our main concerns.

\section{The Anti-Terrorism, Crime and Security Bill}

We have subsequently refined our working methods of scrutiny. The Anti-Terrorism, Crime and Security Bill provides a good example of the challenge we faced in scrutinising legislation introduced as an emergency measure.

The government introduced the Anti-Terrorism, Crime and Security Bill and an accompanying Derogation Order on 12 November 2001, in the wake of the horrific terrorist attacks upon the United States on 11 September 2001.28 The Joint Committee obtained evidence from the Home Secretary, the Rt Hon David Blunkett MP on 14 November 2001. Only two days later, we published an initial report on the Bill, together with a transcript of the Home Secretary's evidence. The Joint Committee subsequently revisited the Bill during the Bill's final stages in the House of Lords. We had to act with great speed if we were to make an effective contribution to debate conducted in an atmosphere of emergency and national security.

27 For example, see (1 May 2001) 625 GBPD cols 566-568 (HL), (8 May 2001) 625 GBPD col 905, (8 May 2001) 625 GPBD col 940.

28 The Human Rights (Designated Derogation) Order 2001 came into effect on 13 November 2001. The coming into force of the Order before the adoption of the Anti-Terrorism Bill allowed the government to issue a section 19 statement that the Bill was compatible with the Human Rights Act 1998. 
In our First Report on the Anti-Terrorism Bill we stated that "[t]he international and national law of human rights, and in particular the provisions of the Human Rights Act 1998, for which we were appointed as the parliamentary guardians, represent core values of a democratic society such as individual autonomy, the rule of law, and the right to dissent, and these must not lightly be compromised or cast away. It is precisely those values which terrorists seek to repudiate and undermine". ${ }^{29}$

We were concerned by the inclusion in the Bill of measures which were neither sufficiently focused nor relevant to constitute emergency legislation. We pointed out that several of the measures had previously been introduced as parts of other government Bills, some of which had been the subject of criticism by the Joint Committee on previous occasions, but which were now being re-introduced by the Home Office without being warranted by any emergency. In our First Report on the Bill, we recommended that "any novel powers should be clearly directed to words combating a novel threat, and should not be used to introduce powers for more wide-ranging purposes which would not have received parliamentary support but for current concerns about terrorism and fear of attack". 30

This opinion was adopted by many critics of the Bill during the parliamentary debates. ${ }^{31}$ Attempts were made to ensure that many of the powers contained in the Bill, particularly the enhanced police powers envisaged by Part 10, would apply only for the purpose of combating terrorist activities.

The government sought to derogate from the right to liberty, protected by Article 5 of the Convention, under Article 15 of the Convention. Article 15 allows States to derogate from some provisions of the Convention "in time of war or other public emergency threatening the life of the nation", but only to the "extent strictly required by the exigencies of the situation". Our Joint Committee reported that the government had failed to produce convincing evidence demonstrating that the measures in Part 4 of the Bill justified the exceptional course of derogating from the Convention. Whilst evidence might exist that following September 11 the United Kingdom was faced with a "public emergency threatening the life of the nation", in the absence of adequate safeguards we did not consider the measures in the Bill to be proportionate or "strictly required by the exigencies

29 Second Report, Session 2001-02, Anti-Terrorism, Crime and Security Bill (16 November 2001), para 4.

30 Second Report, above, para 5.

31 Refer to <http:/ / www.parliament.uk> (last accessed 20 June 2002) for official reports of the debates in both Houses. 
of the situation". In essence, we rejected the government's argument that a derogation from the Convention was justified.

When the House of Lords considered the Derogation Order, the responsible Minister, Lord Rooker, responded to our concerns and sought to explain why a state of emergency existed and why the derogation was strictly required by the situation. In opposing the derogation, Lord MacNally, the frontbench Liberal Democrat peer said: ${ }^{32}$

We are strengthened in [our opposition to the derogation] by the view of both Houses in the Second Report of the Joint Committee on Human Rights. Most noble Lords will have read the report in detail, and in particular paragraph 78. I describe that as the "killer conclusion", although it is one which has already been rejected by the Minister. It states that "we are not persuaded that the circumstances of the present emergency or the exigencies of the current situation meet the tests". It continues with strong words. They are not for the government but for Parliament and this House. It states: "It is now for Parliament to draw its own conclusions, and for Members of both Houses to satisfy themselves that there are adequate safeguards to protect the rights of the individual citizen against abuse of these powers.

Lord McNally proposed that the House decline to approve the Derogation Order. The proposal was subsequently defeated by 148 votes to 69.33

However, the Derogation Order was approved by both Houses. ${ }^{34}$

The Joint Committee's Reports and the parliamentary debates may be influential should the derogation be challenged before British Courts or the European Court of Human Rights. We have recently decided to review the way in which the powers of detention are being exercised under cover of the Act and the Derogation Order, the legitimacy of its continuing application and the process whereby the United Kingdom is permitted to derogate from rights conferred by international human rights instruments in general. $^{35}$

\section{B The Joint Committee's Working Practices}

We have developed our methodology and have adopted the following core decisions:

32 (19 November 2001) 628 GBPD col 883 (HL).

33 (19 November 2001) 628 GBPD col 905-907 (HL).

34 House of Lords: (19 November 2001) 628 GBPD col 883 (HL). House of Commons: (19 November 2001) 375, GBPD cols 125-148 and (21 November 2001) 375 GBPD col 440.

35 The Joint Committee will shortly be calling for written evidence in this regard. 
(1) That every government Bill will be examined at as early a stage as possible to establish whether significant questions of human rights appear to be raised by any of its provisions.

(2) Where such questions appear to arise, written ministerial responses to specific enquiries from the Committee will be sought.

(3) Where it seems appropriate, written commentary from non-governmental sources on these questions will be sought at the same time (this is an area of our work which we are keen to develop).

(4) Ministerial and other responses will be considered, pursued and published alongside any report of the Committee's opinion. On occasions... it will appear to us that the urgency of the matter may require us to report before ministerial responses have been received.

(5) Oral evidence will only be taken in exceptional circumstances. ${ }^{36}$

\section{Early Examination of Bills}

From the beginning, we have aimed to address the issues raised by a Bill at as early a stage as possible, alive to the need to tailor our work to ensure that our reports are published in time to inform each House if possible during the passage of the Bill through Parliament. Where we find that our resources do not permit time for a full and informed inquiry, we publish as a special report the written evidence presented to the Joint Committee, together with correspondence between the Joint Committee and the responsible Minister to inform the debates on the Bill. ${ }^{37}$

\section{Written Ministerial Responses to Specific Inquiries}

We began our very first scrutiny exercise by sending a series of questions regarding compatibility issues to the responsible Minister for written reply. ${ }^{38}$ The questions tackled issues ranging from the compatibility of child curfew orders with the United Nations

36 First Report above, and second report above, para 2.

37 For example, the Third Special Report of Session 2000-01, Scrutiny of Bills (10 May 2001) contained the correspondence between the Chairman of the Committee and the relevant Ministers in relation to several bills, including the Hunting Bill, the Private Security Industry Bill, the Regulatory Reform Bill and the Social Security Fraud Bill. The Special Report noted that "The purpose of this exercise was to gather information and does not imply that the Committee has reached a conclusion about any of the provisions of the bills concerned. The Chairman's letters, and the government's replies, are printed with this Report to inform consideration of these Bills in this or a subsequent session of parliament".

38 This exercise was in relation to the Criminal Justice and Police Bill. 
Convention on the Rights of the Child to privacy issues in relation to Convention rights raised by the retention of fingerprints and DNA evidence by the police. The Minister responsible gave a reply which we regarded as a "model for departmental responses to our inquiries". ${ }^{39}$ It was a detailed defence of the human rights implications of the Bill and its accompanying section 19 statement. ${ }^{40}$

Since our resources would not allow a detailed examination of every Bill introduced in Parliament, ${ }^{41}$ we have delegated to the Chair, Jean Corston MP, the power to write to the Minister, raising questions and concerns regarding human rights issues. ${ }^{42}$ This allows important points to be addressed at a preliminary stage, as part of an ongoing dialogue between the Joint Committee and the relevant Government department.

In the course of its recent examination of the Employment Bill, we sent a letter to the responsible Minister raising two specific human rights issues. We had hoped that the Minister's reply would reach us in sufficient time to allow a Report to be published in advance of the Commons debates on the Bill. In the event, the Minister's reply was too late. However, the government subsequently tabled several amendments which specifically addressed several of the issues causing us concern and significantly improved the Bill.

In our Report on the Police Reform Bill 2002, we published a series of questions we had put in writing to the responsible Minister before receiving his response. The publication of our questions helped inform the House of Lords debate during the Committee stage of the Bill.

\section{Commentary from Non-Governmental Sources}

To ensure that we are informed by a wide range of opinions on the human rights issues raised by key Bills, we canvass evidence from individuals and bodies, including NGOs and expert scholars. ${ }^{43}$ The involvement of non-governmental sources was particularly

39 Joint Committee First Report, Session 2000-01, Criminal Justice and Police Bill (26 April 2001), para 2 .

40 Indeed, Justice in its report Auditing for Rights: Developing Scrutiny Systems for Human Rights Compliance, above has commented (at 60) that the government engaged "positively, enthusiastically, transparently and constructively with the Committee's questions".

41 The Lord Chancellor has accepted that the Committee's resources are finite and that its activities will have to be tailored to ensure its effectiveness: "I believe that the Joint Committee will have to ration itself; it cannot pronounce on every Bill or it will be in permanent session", (4 July 2001) 626 GBPD col 14 (HL).

42 Third Special Report, Session 2000-01, Scrutiny of Bills (10 May 2001).

43 This has become a regular feature of the Committee's approach. 
important in relation to the government's Anti-Terrorism legislation in the aftermath of 11 September 2001. The Government's decision to derogate from Article 5 of the Convention provoked widespread public concern and criticism. Two key influential British human rights NGOs, JUSTICE and Liberty, commissioned independent opinions from expert legal counsel on the legality of the derogation in the terms proposed by the government. ${ }^{44} \mathrm{~A}$ large number of written submissions and briefings were also presented to the Joint Committee. We published, as part of our Report on the Anti-Terrorism legislation, both the evidence of the organisations and the supporting legal advice. ${ }^{45}$

\section{Consideration of Ministerial Responses}

Our Reports contain our observations on Ministers' reasons for considering that a Bill is compatible with Convention and other relevant human rights. For example, we were particularly concerned that the Proceeds of Crime Bill 2001 would require the courts to make confiscation orders on the ground that the defendant had a "criminal lifestyle" and that this could lead to the imposition of disproportionate penalties in breach of Article 6 of the Convention. We raised these points by letter to the Minister, and our Report observed that: "We are inclined to doubt the government's assertion that "there will always be evidence supporting the assumptions, namely that the defendant has been convicted of an offence that is indicative of a criminal lifestyle". ${ }^{46}$ We explained our conclusion by reference to the low evidential threshold in the Bill, the weight of the statutory presumption it created, and the lack of empirical evidence provided by the government to demonstrate that the criteria provided in the Bill for the assessment of "criminal lifestyles" reflected objectively verifiable data.

\section{Oral Evidence}

I have already mentioned that, in relation to the Criminal Justice and Police Bill, the Joint Committee praised "the careful and serious way in which the Minister and his officials approached the process which seems to indicate the importance which the Home Office attaches to human rights standards". ${ }^{47}$ However, while we have found taking of

44 See Fifth Report, Session 2001-02, Anti-Terrorism Crime and Security Bill (16 November 2001), Appendix 3: Joint Opinion prepared for JUSTICE by David Anderson QC and Jemima Stratford on the proposed derogation from ECHR Article 5 and Appendix 5: Opinion of David Pannick QC prepared for Liberty (the National Council for Civil Liberties) on the derogation from ECHR Article 5.

45 Fifth Report, Session 2001-02, Anti-Terrorism, Crime and Security Bill Further Report (5 December 2001).

46 Eleventh Report, Session 2001-02, Proceeds of Crime Bill: Further Report (11 February 2002).

47 First Report, Session 2000-01, Criminal Justice and Police Bill (26 April 2001), para 3. 
oral evidence to be valuable, the process is both time-consuming and resource-intensive. This, together with the Government's open engagement with our requests for written evidence means that much of our business can be conducted effectively on paper. Of course, some issues require the taking of oral evidence. Gathering evidence in person gives us the opportunity to interact with Ministers and other government officials on a more direct and immediate basis than through an exchange of papers, and may have more influence on Ministers than a purely impersonal written procedure.

For example, during the oral evidence from the Rt Hon David Blunkett MP, the Home Secretary sought to give full answers to the questions posed by the Joint Committee Members and made a number of concessions. Vera Baird QC MP put several questions to the Home Secretary regarding Part 4 of the Bill. This Part contained the most controversial proposals of the Bill, giving the Home Secretary the power to certify that certain individuals, "suspected of international terrorism", who could not be deported without acting in breach of their right to life or right to be free from torture, could be held indefinitely for the purposes of securing their deportation. It was these provisions which potentially engaged the right to liberty protected by Article 5 of the Convention and led the government to enter a derogation from the Convention. The Home Secretary conceded that his belief that an individual was "suspected of international terrorism" should be based upon reasonable grounds. The government subsequently amended the Bill in this respect. ${ }^{48}$

During discussions about Part 5 of the Anti-Terrorism Crime and Security Bill, which contained provision to introduce an offence of "incitement to religious hatred", 49 in view of the free speech dimension, we questioned the Home Secretary about why the Government had not introduced provisions to abolish the obsolete offence of blasphemy. ${ }^{50}$ The Home Secretary responded positively and commented that "there will come a moment when it will be appropriate for the blasphemy law to find its place in history". 51

Two days after taking oral evidence, we published a short Report on the Bill and the Derogation Order, accompanied by a transcript of the Home Secretary's evidence. This meant that Parliament had before it a wider understanding of the government's thinking

48 Second Report, Session 2001-02, Anti-Terrorism, Crime and Security Bill (16 November 2001) 5. See the evidence of Mr Blunkett, paras 30-33.

49 Subsequently removed from the Bill.

50 Campaigners have argued for many years that the offence should be abolished on the ground that it explicitly discriminates in providing protection to people of the Christian faith.

51 Second Report, above, para 49. 
as to the objects of the Bill and the purported justification for the need to derogate from the Convention's right to liberty. ${ }^{52}$

Ministers do not always take kindly to questions raised by the Joint Committee on Human Rights. There was a rather intemperate outburst by the Minister of State at the Home Office, Lord Rooker, when we raised a question about the powers to be given to British Transport Police in the Employment Bill in relation to the removal of truants from railway property. Lord Rooker described the Committee as having "taken leave of its senses". He continued: ${ }^{53}$

[t] he only reason the British Transport Police are involved is that someone is on railway property, so how can we be depriving someone of his or her liberty under the Human Rights Act? If that question is what I think it is, it gives the Human Rights Act the exact bad name that we do not want it to have by making preposterous allegations, or by raising issues in such a way that the general public would say that members of the Joint Committee are not living in the real world. The British Transport Police are there to look after railway property. That is their role and function. Truants - people on the property - would be removed. That is what the clause is about - removing people. We are not depriving anyone of his or her liberty. Is it depriving someone of his or her human rights if we remove a truant from railway property? That sounds preposterous. I know that I shall get it in the neck from members of the Joint Committee, but that is up to them.

The Joint Committee decided that it was not necessary to respond to the Minister personally, but to deal with the substantive issues. ${ }^{54}$

\section{THE EVOLVING IMPACT OF SCRUTINY ON THE LEGISLATIVE PROCESS}

We do not seek to make general criticisms of legislative proposals. Where we consider that a provision can be improved to compatibility, we recommend that the Bill should be remedied on its face to make the relevant human rights standard explicit. This reduces the need for judicial interpretation of the scope of the new provision, providing greater legal and administrative certainty. We have observed that "as a general principle...rights and powers should be express in legislation, even though the effect of the Human Rights Act

52 Second Report, above, Minutes of Evidence.

53 (12 March 2002) 632 GBPD col 727 (HL).

54 Fifteenth Report, Session 2001-02, Police Reform Bill: Further Report (25 March 2002). 
would be to imply compatible standards". ${ }^{55}$ This approach in turn assists the courts if it results in legislation which better accords with the principle of legal certainty.

In our recent Report on the Police Reform Bill 2002, we criticised the breadth of the delegated powers given to the Secretary of State in the Bill to allow him to extend additional powers to civilian officers. We considered that such extensive delegated power was inappropriate because it authorised possible breaches of Convention rights without adequate safeguards. ${ }^{56}$ We emphasised "the importance of expressing the constraints on the use of statutory powers alongside the powers in primary legislation, in order to make the extent of the powers (and of any authorised interference with human rights) clear and accessible on the face of the legislation". ${ }^{57}$

\section{A Scrutiny of non-Governmental Bills for Human Rights Compliance}

In contrast to section 7 of the New Zealand BORA, which requires the AttorneyGeneral to report on any Bill which is inconsistent with the Act, the HRA does not require Ministerial or any other statements of compatibility in relation to Private Bills or Private Member's Bills. ${ }^{58}$ Section 19 covers only Government Bills. However, the Standing Orders of each House have been amended to require the promoter of a Private Bill to produce a statement of opinion as compatibility with the Convention rights. ${ }^{59}$ The Joint Committee has therefore undertaken to examine Private Bills in much the same way as it examines government Bills.

Similarly, the Joint Committee has decided to examine Private Members' Bills for Convention compliance. We produce a short brief on each Private Member's Bill introduced into Parliament rather than expecting the sponsor of the Bill to provide written

55 Eleventh Report, Session 2001-02, Proceeds of Crime Bill: Further Report (11 February 2002), para 6.

56 Thirteenth Report, Session 2001-02, Police Reform Bill (4 March 2002), para 9.

57 Fifteenth Report, Session 2001-02, Police Reform Bill: Further Report (25 March 2002).

58 In fact, only eight of the twenty-two Attorney-General's Reports under section 7 BORA have related to government Bills.

59 The Standing Orders of each House were amended with effect from 27 November 2001, so that Standing Order 38(3) of both Houses now require the Memorandum attached to each Bill by the responsible Minister to include a statement of opinion as to compatibility of the Bill with Convention rights. Standing Order 169A of the House of Commons and Standing Order 98A of the House of Lords require a Minister to report on each such statement immediately after First Reading of the Bill. 
responses to questions we may have. We have recently decided to give the sponsors of Private Member's Bills the opportunity to respond should they so wish. ${ }^{60}$

We have so far drawn to the attention of Parliament to three Private Members' Bills raising human rights issues. We have decided to comment upon those aspects of the Bills which would have a positive impact upon the protection of human rights in the United Kingdom. The first Private Member's Bill on which the Joint Committee reported was the Tobacco Advertising and Promotion Bill, introduced by Lord Clement-Jones in terms identical to a previous government Bill. ${ }^{61}$ In these circumstances, we sought written responses from the Department of Health and the Department of Trade \& Industry, which were given. ${ }^{62}$ In our Report, we recommended that the Department of Health should make available the evidence relating to the anticipated effect of the prohibition of certain types of tobacco advertising or promotion to enable Members to draw their own conclusions about the proportionality between the public interest ends that might be served by such prohibition and the means used to achieve them. In the event, we received a letter from Yvette Cooper MP, the Minister for Public Health, which we appended to our Report.

In reporting positively on Kevin McNamara MP's Treason Felony, Act of Settlement and Parliamentary Oath Bill, we noted that:

In decriminalising the promotion of a republican form of government and providing for an alternative form of parliamentary oath, the Bill would also enhance the protection for the right to freedom of conscience under ECHR Article 9, the right to freedom of expression under ECHR Article 10, and the right to be free of discrimination on the grounds of political opinion under ICCPR Article 26 and under Article 14 of the ECHR taken together with Article 10 of the ECHR and Article 3 of the Protocol No1 to the ECHR. that: ${ }^{63}$

In reporting favourably on my own Civil Partnerships Bill, the Joint Committee noted

the Bill removes legal disabilities which have previously afflicted those who have been effectively unable to contract a marriage, for example transsexuals and homosexuals. It would

60 Fourteenth Report, Session 2001-02, Scrutiny of Bills: Private Members' Bills (8 March 2002).

61 The Government Bill was lost at the dissolution of Parliament and not subsequently reintroduced by the Government.

62 Eighth Report, Session 2001-02, Tobacco Advertising and Promotion Bill (19 December 2001). The Committee has now adopted this approach as a useful precedent where the content of the Bill is of government origin.

63 Fourteenth Report, Session 2001-02, Scrutiny of Bills: Private Members' Bills (8 March 2002), para 17. The Committee also published the legal opinion on compatibility with the ECHR produced by Mr David Pannick QC. 
also offer other people an additional method of publicly entering into a lasting commitment with each other in a way which would have many of the legal consequences of marriage.

\section{B Increasing the Transparency of Section 19 Statements}

Under section 7 of the BORA, ${ }^{64}$ where the Attorney-General finds some incompatibility, she has an obligation to disclose the legal advice that she has given to her colleagues in government. ${ }^{65}$ By contrast, in the United Kingdom, it is the Joint Committee, rather than the Law Officers, that gives detailed advice to Parliament both on the compatibility and incompatibility of government measures.

At first, the government did not accept that, to fulfil its purpose, a section 19 certificate should be accompanied by a fuller explanation of the responsible Minister's reasons for believing the Bill is compatible with Convention rights. When the HRA was enacted in 1998, the government argued that a debate in Parliament provided the best forum in which the Minister responsible can explain his or her thinking on the compatibility of the Bill with the Convention rights; "[w]e believe that the best forum in which to raise issues concerning the compatibility of a Bill with the Convention Rights is the parliamentary Proceedings on the Bill". 66

However, as our early consideration of section 19 statements demonstrated, effective scrutiny depends both upon Government co-operation and the informed participation of individual Parliamentarians with sufficient energy and expertise to ensure that the relevant issues are raised and addressed. Without prior notice of the Government's section

64 See also Standing Order 260(2) of the Standing Orders of the House of Representatives.

65 However, the Attorney-General must only produce a report where she considers, on the basis of the legal advice she has received from the Ministry of Justice or the Crown Law Office, that there is some inconsistency with the legislation concerned and the BORA. Since 1990 only eight Government Bills have prompted the Attorney General to place a section 7 report before parliament. However, the Ministry of Justice examines all Bills for compliance. This legal advice is not revealed to the public where the Attorney General decides not to report. In 1999, the Ombudsman, in reviewing the Attorney-General's decision not to reveal such a piece of legal advice in response to a request under the Official Information Act (OIA), held that as the Attorney-General is not listed in the relevant schedules which define the organisations subject to the OIA and she was not therefore required to disclose the legal advice provided by the Ministry of Justice.

66 Lord Williams of Mostyn's Written Answer, (10 December 1998) 595 GBPD, WA 116 (HL). In its briefing on the Bill, JUSTICE noted that without further "detail and certainty", section 19 would not fulfil its potential. In its recent Report "Auditing for Rights: Developing Scrutiny Systems for Human Rights Compliance", it concluded: "By not providing reasons to assist Parliament, the legislative branch of government will play a lesser role within the scheme of the HRA. A possible consequence of this may be legislation passed through parliament which may breach Convention rights, thus requiring the courts to take the lead role in protecting rights". 
19 justifications, parliamentary time is unnecessarily wasted seeking to discover the rationale for the Government's views.

Accordingly, we pressed Ministers to give a written statement at an earlier stage, ideally upon publication of a Bill, so as to enable us to carry out our scrutiny work more efficiently and to give timely advice during the passage of legislation. ${ }^{67}$ During our investigation into the implementation of the HRA, both the Home Secretary and the Lord Chancellor explained that their minds were open on this issue but that they were concerned to protect the legal privilege normally accorded to the advice of the law officers. ${ }^{68}$

The Government has now responded positively. ${ }^{69}$ Since 1 January 2002, the Explanatory Notes published with every government Bill contain an outline of the government's views on compatibility. The first of these new-style Explanatory Notes accompanied the recent Police Reform Bill 2002. In our Report on the Bill, we welcomed the introduction of this new, more open approach: "This greatly assisted the Committee, by making it easier to see what issues have been considered". ${ }^{70}$ The Joint Committee's correspondence with the Minister was usefully informed by the content of the Explanatory Notes, allowing for a more detailed and focused exchange. Nevertheless, we continue to press for fuller statements of reasons as an aid to parliamentary debate and legislative certainty. In our Further Report on the Police Reform Bill 2002, we stated that: "We welcome this development, which enhances the value of the statement under section 19(1)a by showing which rights the Minister has considered. At the same time, we note that the Explanatory Notes do not set out in very much detail the Minister's reasons for concluding that the provisions of the Bill were compatible with those rights. The Explanatory Notes would be of more use to each House if somewhat fuller reasoning were

67 Prior to the establishment of the Committee, several individual Peers tabled parliamentary questions pressing the government to further define the scope of their responsibilities under section 19. I asked the government to provide reasons to accompany the publication of a section 19 statement. For examples see (10 December 1998) 595 GBPD WA 43 (HL), (17 December 1998) 595 GBPD (HL).

68 See Minutes of Evidence, Implementation of the Human Rights Act 1998 (The Rt Hon Jack Straw, MP) (14 March 2001), para 27 and Minutes of Evidence, Implementation of the Human Rights Act 1998 (The Rt Hon Lord Irvine of Lairg) (19 March 2001), para 57.

69 "The government have agreed to changes to the relevant guidance so that the explanatory notes of all government Bills first introduced after 1 January 2002 will draw attention to the main convention issues raised by a Bill. I hope that this will further assist Parliament in its debates on these matters": the Lord Chancellor's Written Answer, (18 December 2001) 629 GBPD, WA 116 (HL).

70 Fifteenth Report, Session 2001-02, Police Reform Bill: Further Report (25 March 2002). 
to be provided". ${ }^{71}$ The government has also confirmed that the Explanatory Notes relating to a Bill will be updated when a Bill is transferred from the House of Commons to the House of Lords and again on completion of the Bill's passage in order to take account of any amendments to the Bill or any significant human rights issues raised in debate. ${ }^{72}$ This is a further welcome development.

\section{MAKING REMEDIAL ORDERS UNDER THE HUMAN RIGHTS ACT.}

The Joint Committee also scrutinises other matters. We have entered into a constructive dialogue with the Government in relation to the operation of judicial declarations of incompatibility under section 4, and remedial orders under section 10 of the HRA. Section 10 provides for the introduction by the Government of so-called fast-track "remedial orders" to change the law where United Kingdom Courts have determined that an incompatibility between domestic law and a Convention right cannot be remedied by robust interpretation under section 3 and have accordingly made a declaration of incompatibility under section 4 of the HRA, or where the European Court of Human Rights have concluded that a provision of United Kingdom law breaches the Convention.

The HRA sets out the procedure by which the Minister responsible should exercise his power to issue "remedial orders". There are essentially two forms of procedure: urgent and non-urgent. ${ }^{73}$ In accordance with its terms of reference, the Joint Committee recommends to Parliament whether or not it should approve the remedial order in question. $^{74}$

The first remedial order made under the HRA, was introduced to amend the Mental Health Act 1983 to remove an incompatibility between the procedures prescribed to be followed by Mental Health Tribunals, to determine whether the criteria for an individual's detention continued to justify his or her detention and the right to liberty under Article 5 of the Convention. This gave us the opportunity to consider the procedures envisaged by the

71 Fifteeenth Report, above.

72 (19 March 2002) 632 GBPD, WA 127 (HL).

73 Schedule 2 to the HRA sets out the procedure for making remedial orders. The non-urgent procedure requires a Minister to make a proposal for an order and consult upon it before laying the order in draft before Parliament. The draft order is then subject to an affirmative resolution of both Houses. The urgent procedure allows an order to be made and laid before Parliament without consultation. However, the draft order will cease to have effect if it is not approved by both Houses within 120 days of being made.

74 As set out in the Terms of Reference of the Committee's Sixth Report, Session 2001-02, Mental Health Act 1983 (Remedial) Order 2001 (19 December 2001) pursuant to Standing Order Nos 73 (Lords) and 151 (Commons) (Statutory Instruments (Joint Committee)). 
HRA, and to examine the government's approach to declarations of incompatibility and remedial orders.

We approached the Draft Remedial Order initially as we would any other scrutiny exercise, by requesting information from the responsible Minister. ${ }^{75}$ We were concerned that the Government had decided to use the non-urgent procedure in circumstances where the continuing operation of the offending provision had a significant impact on the liberty of the individuals concerned. The Minister accepted our concerns and re-tabled the Order using the urgent procedure. ${ }^{76}$

The Joint Committee raised a number of other issues, ${ }^{77}$ including the possibility of compensation for those individuals affected by the incompatibility and recommended that parliament should approve the order. ${ }^{78}$ In our Report we noted that this recommendation was not subsequently adopted by Government. We concluded that "[w]e remain of the opinion that the inclusion of a statutory compensation scheme in the remedial Order would have been appropriate" but did not insist on pursuing the issue. ${ }^{79}$

We have now published a report considering the lessons learnt from our consideration of the Draft Order. ${ }^{80}$ We have recommended several amendments to the Standing Orders of both Houses and to the HRA in order to ensure that, under the urgent procedure, the Joint Committee's reports will inform parliamentary debate on the content and scope of the Order. ${ }^{81}$ We have also suggested that certain safeguards be added to consideration of Remedial Orders by the House of Commons to ensure a greater level of scrutiny than is usually given to delegated legislation. The government has not yet responded to our proposals to improve remedial order procedures, although the House of Commons Procedure Committee has endorsed them so far as they fall within their remit. ${ }^{82}$

We have considered the way in which the responsible Minister should approach her powers under section 10 in order to make the procedure more effective. We have

75 Sixth Report, above, para 4.

76 Sixth Report, above, para 6.

77 Sixth Report, above, para 14.

78 Sixth Report, above, paras 19-29.

79 Sixth Report, above, para 38.

80 Seventh Report, Session 2001-02, Making of Remedial Orders 2001 (19 December 2001).

81 Seventh Report, above, set out in detail in Annex B.

82 House of Commons Procedure Committee, First Report, Session 2001-02, Making Remedial Orders: Recommendations by the Joint Committee on Human Rights. 
recommended that where the United Kingdom or Strasbourg Courts have delivered a judgment which could trigger the making of a remedial order, the Joint Committee should be informed (and be provided with a copy of the judgement) as a matter of course and within strict time limits. ${ }^{83}$ In relation to a Strasbourg judgement, even where the Minister does not intend to introduce a section 10 Order, we have suggested that the Minister should inform the Joint Committee of any steps the Minister intends to take to ensure that similar violations do not occur in future. Where a Minister subsequently decides not to appeal against a declaration of incompatibility made by a lower court, the Joint Committee has requested that it be furnished with detailed reasons for that decision. Once a judgment containing a declaration of incompatibility has become final, the responsible Minister should inform the Joint Committee of her preliminary view on how the government intends to remedy the incompatibility, giving reasons for their approach. A final decision on how to treat a declaration should be taken within six months of the final judgement. We are still awaiting a governmental response to our recommendations.

We have explained the considerations which we suggest should be taken into account in deciding whether to adopt the urgent or non-urgent procedure: ${ }^{84}$

- The significance of rights which are, or might be, affected by the incompatibility;

- The seriousness of the consequences for identifiable individuals or groups from allowing the continuance of an incompatibility with any right.

- The adequacy of compensation arrangements as a way of mitigating the effects of the incompatibility.

- The number of people affected.

- Alternative ways of mitigating the effect of the incompatibility pending amendment to primary legislation.

The Joint Committee considered that "the decisive factor should be the current and foreseeable impact of the incompatibility on anyone who might be affected by it". .5

\section{CONCLUSION}

I hope that this account of the work done by the Joint Committee during its first year is of interest and relevance in New Zealand. The experiment hasbeen successful in increasing the impact of the HRA and the Convention, and of international human rights law

83 Seventh Report, above, para 26.

84 Seventh Report, above, paras 36 and 37 and Annex A.

85 Seventh Report, above, para 36. 
generally, on Ministers, civil servants, and Parliamentarians. NGOs have become an important part of the process, and the members of our Committee, drawn from each of the main political parties as well as from the cross-bench, have worked well together to produce focused and informative reports on complex and controversial issues of public policy.

I have written elsewhere about what the Cabinet papers reveal about the true motivation of Harold Wilson's administration in introducing the Commonwealth Immigrants Bill 1968, an unsightly measure that deprived some 200,000 British citizens of East African Asian origin of their right to enter and live in the United Kingdom - their only country of citizenship. ${ }^{86}$ The official records, released under the Thirty Year Rule reveal how cursory and superficial was the consideration given within government and by Parliament to the possible breaches of international human rights law that this legislation involved. Ultimately, it was left to the European Commission of Human Rights to reach the damning conclusion that Parliament had violated Article 3 of the Convention in the exercise of its legislative powers. In the Commission's words, publicly to single out a group for differential treatment on racial grounds constituted a special affront to human dignity, and the statute had subjected this group of British citizens to degrading treatment.

If such a measure were to be introduced by a future government which decided that it was more expedient to defer to than to resist popular prejudice and intolerance, scrutiny within Whitehall, by Parliament, and by the courts of its compatibility with domestic and international human rights law would be not only better informed but much more rigorous, within the framework of the HRA.

In the first place, there is now a well-developed body of jurisprudence under the Convention in which British judges and lawyers are well trained. Secondly, the obligation imposed by section 19 upon the responsible Minister to make a compatibility statement has greatly intensified scrutiny in Whitehall. Thirdly, the existence of the Joint Committee with a broad mandate and expert legal adviser means that there is a public watchdog to scrutinise Ministerial statements of compatibility and their reasons, focusing not only on the Convention but also upon the other international human rights codes. Fourthly, the fact that British courts are empowered to make declarations of incompatibility means that the alleged victims of a similar measure today would have direct access to our courts to obtain a declaration that would either induce the government to take remedial action or to provide valuable support in a claim to the European Court of Human Rights. British courts would be well placed to establish the relevant facts about the aims and effects of the measure.

86 Lord Lester of Herne Hill "Thirty Years On: The East African Asians Case Revisited" [2002] PL 52. 
The institutional and legal safeguards against the misuse of executive and legislative powers in this country are much stronger now than they were in 1968. They may not in themselves be sufficient to guarantee that a future government, Parliament and judiciary would protect unpopular or vulnerable groups against what Justice Robert Jackson described as "the great currents of intolerance, passion, usurpation, and tyranny which have threatened liberty and free institutions". 87 However, they provide an essential bulwark, and they promote a culture of respect for fundamental rights and freedoms which are, or ought to be, our constitutional birthright.

87 Robert Jackson The Supreme Court in the American System of Government (Harvard University Press, Cambridge, 1955), 80. 
